\title{
Species composition and diversity of mites associated with honeybees Apis mellifera L in the Egyptian apiaries
}

\author{
Abd El Hady M. A. H. ${ }^{\mathrm{a}^{*}}$, Mahfouz H. M. ${ }^{\mathrm{b}}$ \\ ${ }^{a}$ Department of Agriculture Zoology and Nematology, Faculty of Agriculture, Al-Azhar University, Cairo, Egypt \\ ${ }^{b}$ Department of Plant Production, Faculty of Environmental Agricultural Sciences, Arish University, Arish, Egypt
}

\begin{abstract}
Honeybees are social insects that live in colonies and play an important role in agricultural production. These insects are the main source of honey in additional to other products such as: royal jelly, wax and pollen, as well some other products like propolis and poison that can be used as a treatment for certain human diseases. However, the important role of that bees play in pollinating crops cannot be overlooked, as bees are the most common insect species. Also, one third of the food consumed daily depends on the role of bees in pollination crops. On the other hand, a lot of mites take honeybees as a suitable habitat including nonparasitic, omnivorous, and pollen-feeding species, and parasites. The latter may cause severe diseases for bees. The bio-relationships between mites and bees have been attracted the attention of many researchers, they concluded that the association between mites and bees could be ecto or endo parasites, phoretic, exudate feeders, predaceous and fungivorous. So, it was necessary to throw more light on mites in honeybees' colonies and apiaries. From the following data it can be announced that, a total of 30 species of mites belonging to 15 families have been recorded from different governorates of Egypt. Some collected mites were predators on other mites and small arthropods, while others feed on pollen, old provisions or use the honeybees just for transport from a place to another. The Varroa destructor was the most collected and the most dangerous parasitic mite of the honeybee, A. mellifera $\mathrm{L}$ worldwide collected from all the studied governorates of Egypt.
\end{abstract}

Keywords: honeybees, parasites, relationships, mites, incidence, Apis mellifera.

*Corresponding author: Abd El Hady M. A. H., 


\section{Introduction}

Honeybee (Apis mellifera L.) is considered as one of the most important insects all over the world including Egypt, that lives in a society and show some degrees of social behavior and cannot survive as individually but require the social setting of a colony. Mankind has benefited from honeybees for thousands of years as food and medicinal purposes, in addition to other products. Also, one of the most important roles of that honeybees pollinating of the plants. Recently under Egyptian conditions beehives are infected with many pests including the Acarapis woodi, Varroa jacobsoni and Tropilaelaps clareae are known the honeybee's main pests (Neumann and Carreck, 2010; Wakhal et al., 1999; Ward et al., 2008). However, about 100 mite species mostly harmless are associated with honeybees (Eickwort 1988). Those mites affect honeybee hives may be divided into three groups: parasites, phoretic mites, and house guests. As for species may be relatively few, but some cause many serious diseases to bees (Ahn et al., 2015; Diana-Sammataro, et al., 2000; Mordecai et al., 2016). Several authors have studied the incidence of the mites associated with honeybees in different countries around the world. The current study focused on surveying and studying mite species that associated with honeybees and their economic importance in honeybee hives in several Egyptian governorates.

\section{Materials and methods}

\subsection{Areas of study}

The current study was conducted in 9 regions from three Egyptian governorates (three regions for each governorate), during the two successive years (2019 and 2020), to study the prevalence and diversity of mite species associated with honeybee (A. mellifera L.) hives. These governorates are Giza (El-Aiat, El-Saf and Atfeeh), Sharkeia (Belbes, Hihya and Faqous) and Faiyum (Faiyum, Tamiya and Ibsheway).

\subsection{Methods of samples}

Different methods were used in order to collect mite species associated with honeybee during this study, either from the bodies of honeybee workers or from hives floor. The bee workers, adult bee, were brushing from the brood combs into jar containing $75 \%$ ethyl alcohol, then shacked out for a few minutes until the bees strained out. The jar contents were filtered by using a piece of white cloth. The yielded materials were examine under a stereo-binocular microscope, and to continuously monitor the level of mite infestations in hives, a sheet of white paper or plastic sheet can be placed on the bottom boards under a wire frame, where falling mites were trapped and wire kept 
bees from removing mites (De Jong et al., 1982). On the other side brood combs of infested bees were banged on a table covered with a piece of dark paper. Dislodged mites may be seen running over the paper and picked up with a fine brush wetted with alcohol (Morse, 1978). Also modified Tullgren's funnels were used to extract deferent mite species from the hive debris, pollen, dead bees and brood combs, by using 40-Watt bulb for 6 h. The mites were received in Petri-dishes filled with water. Most of mite species were individually mounted directly in Hoyer's medium, on glass slide, dried in an oven at $50-55^{\circ} \mathrm{C}$ to stretch the mites and rendering them clear and transparent labels including the necessary information were stoked to the slides then examined under a research microscope.

\subsection{Identification of mite species}

The identification of mite species associated with honeybee was based on illustrated keys of Lindquist and Evans (1965), Summers and Price (1970), Balogh (1976), Hughes (1976), Krantz (1978), Evans and Till (1979), Zaher (1984) and Zaher (1986).

\section{Results and Discussion}

The current study showed that, presence of 30 mite species belonged to 15 families extracted from beehive debris, pollen, dead and active bees and brood combs are commonly associated with honeybee in three Egyptian governorates (Giza, Sharkeia and Faiyum) these mites may be divided into: ecto or endo parasites, phoretic, exudate feeders, predaceous and fungivorous. The collected mites are belonging two orders [parasitiformes including suborder Gamasida (Mesostigmata), and order Acariformes including three suborders Actinedida (Prostigmata), Acaridida (Astigmata) and Oribatida (Cryptostigmata)]. Suborder Gamasida (Mesostigmata) was represented by seven families and fourteen species [Ascidae (5 species), Rhodacaridae (one species), Parasitidae (one species), Laelapidae (3 species), Amerosiidae (two species), Uropodidae (one species) and Varroidae (one species)]. The Mesostigmata mites composed mostly of predaceous or parasitic species, (Ghada-Refaei, 2001). Suborder Actinedida (prostigmata) was represented by four families and eight species [Tydeidae (two species), Pygmoforidae (one species), Scutacaridae (one species) and Cheyletidae (four species)]. Then suborder Acaridida was represented by two families [Acaridae (four species), Glycyphagidae (two species)]. Also, suborder Oribatida was represented by two families [Oppidae (one species) and Oribatulidae (one species)] (Table 1). 
Table (1): Species composition and diversity of mites inhabiting honeybee hives in three Egyptian governorates.

\begin{tabular}{|c|c|c|c|}
\hline Family & Mite species & Locality & Abundance \\
\hline \multicolumn{4}{|c|}{ Suborder: Gamasida } \\
\hline \multirow{5}{*}{ Ascidae } & Blatosciocius tarsalis (Berlese) & G & + \\
\hline & Blattisocius mali (Oudemans) & $\mathrm{S}$ & + \\
\hline & Blattisocius $\mathrm{sp}$ & $\mathrm{G} \& \mathrm{~S}$ & + \\
\hline & Proctolaelaps peygmaeus (Muller) & $\mathrm{F}$ & + \\
\hline & Proctolaelaps oriantalis Nasr & $\mathrm{S}$ & + \\
\hline Rhodacaridae & Rhodacarus roseus Oudemans & F \& G & + \\
\hline Parasitidae & Parasitus consanguineous Oudemans and Voigts & $\mathrm{S}$ & + \\
\hline \multirow{3}{*}{ Laelapidae } & Androlaelaps kifli Metwally and Ibrahim & G\& F & + \\
\hline & Hypoaspis whabi Metwally and Ibrahim & G\& F & + \\
\hline & Ololaelaps brevetova Shreef and Soliman & $\mathrm{F}$ & ++ \\
\hline \multirow{2}{*}{ Ameroseiidae } & Kleemannia plumosus Oudemans & $\mathrm{S}$ & + \\
\hline & Ameroseuis aegypticus El Badry, Nasr and Hafiz & $\mathrm{G}$ & ++ \\
\hline Uropodidae & Uroobovella sp & $\mathrm{G}$ & + \\
\hline Varroidae & Varroa destructor Anderson \& Trueman & All studied Gov & +++ \\
\hline \multicolumn{4}{|c|}{ Suborder: Actinedida } \\
\hline \multirow{2}{*}{ Tydeidae } & Paralorryia wooleyi Baker & $\mathrm{F}$ & + \\
\hline & Tydeus kochi Oudemans & $\mathrm{G}$ & ++ \\
\hline Pygmoforidae & Pediculaster $\mathrm{sp}$ & $\mathrm{S}$ & + \\
\hline Scutacaridae & Scutacarus evansi Soliman \& Kandil & $\mathrm{S}$ & + \\
\hline \multirow{4}{*}{ Cheyletidae } & Acaropsella notchi Volgin & $\mathrm{F}$ & ++ \\
\hline & Cheletomorpha lapidopterus (Shaw) & $\mathrm{G}$ & + \\
\hline & Cheyletus malaccensis Oudemans & $\mathrm{S}$ & ++ \\
\hline & Hemechyletia bakeri (Ehara) & $\mathrm{F}$ & ++ \\
\hline \multicolumn{4}{|c|}{ Suborder: Acaridida } \\
\hline \multirow{4}{*}{ Acaridae } & Acarus farris Oudemans & G\&S & ++ \\
\hline & Caloglyphus mycophagus (Megnin) & $\mathrm{F}$ & + \\
\hline & Caloglyphus rhizoglyphoides (Zacbvatkin) & All studied Gov & +++ \\
\hline & Thyreophagus entomophagus (Laboulbene) & All studied Gov & ++ \\
\hline \multirow{2}{*}{ Glycyphagidae } & Glycyphagous ornatus Kramer & G \& F & ++ \\
\hline & Lapidoglyphus michaeli (Oudemans) & G\&F & ++ \\
\hline \multicolumn{4}{|c|}{ Suborder: Oribatida } \\
\hline Oppidae & Oppia bayoumi Shreef \& Zaher & G\&S & + \\
\hline Oribatulidae & Zygoribatulo tameyai El-Badry and Nasr & G\&S & + \\
\hline
\end{tabular}

Signs: +: rare (1-3 mites), ++: moderate (3-9 mites), +++: high (more than 9 mites), G= Giza governorate, $\mathrm{F}=$ Faiyum governorate, $\mathrm{S}=$ Sharkeia governorate .

On other hand seven families of mesostigamid mites were recorded in association with honeybee, including, Ascidae Voigts and Oudemans which was represented by five species belonging to two genera Blatosciocius tarsalis (Berlese) from Giza governorate, Blattisocius mali (Oudemans) from Sharkeia and Blattisocius sp from Giza and Sharkeia governorates, in addition to
Proctolaelaps peygmaeus (Muller) and Proctolaelaps oriantalis Nasr recorded from Faiyum and Sharkeia governorates. These mites were found in scarce numbers feeding on dead bees, brood comb and hive debris, in agreement with data obtained by O'connor and Klimov (2004), Ghada- Refaei et al. (2018). The family Rhodacaridae Oudemans was represented by a single species Rhodacarus roseus 
Oudemans, which was collected from beehive debris with rare numbers at Giza and Faiyum governorates, in agreement with Sammataro et al. (2000). The parasitid mite Parasitus consanguineous Oudemans and Voigts which was found phoretic on adult bees and feed on other small arthropods and rarely recorded from samples of hive debris in Giza and Sharkeia governorates (Ghada- Refaei, 2001; Oconnor, 2004; Oconnor and Klimov, 2004). Androlaelaps kifli Metwally and Ibrahim, Hypoaspis whabi Metwally and Ibrahim and Ololaelaps brevetova Shreef and Soliman were collected from beehive debris in scare numbers from Giza and Faiyum governorates. While, the $O$. brevetova was collected in moderate numbers from Faiyum governorate. In general, laelapid mite species doesn't cause any significant damage in spite of being collected from bees worldwide because, most of them feed on old provisions, small arthropods, pollen or phoretic on bees (O'Connor and Klimov, 2004). The family Amerosiidae Evans was represented by two species Kleemannia plumosus Oudemans which was rarely recorded from samples of hive debris at Sharkeia governorate, and Ameroseuis aegypticus El Badry, Nasr and Hafiz which was recorded in moderate numbers from samples of hive debris in Faiyum governorate. Members of family Uropodidae Berles are freeliving mites inhabiting debris, organic manures, insect nests feed on fungi. Only a single species, Uroobovella $\mathrm{sp}$ was rarely collected from bees and hive debris at Giza governorate without any damage to beehives as reconfirmed by Refaei (2005). The most serious ectoparasitic mites to A. mellifera $\mathrm{L}$ are belonging to family: Varroidae Delfinado \& Baker, (Varroa jacobsoni) and (Varroa destructor Anderson \& Trueman) the Varroa mites were found in most of the studied hives, feeding on the internal tissue of all developmental stages of honey bee, causing a severe damage often leading to the loss of colonies and is considered as one of the reasons for transmitting certain virus diseases (Mordecai et al., 2016). Also, the Actinedida is represented by four families and eight species association with honeybee. The family Tydeidae Kramer is represented by two species (Paralorryia wooleyi Baker and Tydeus kochi Oudemans). The first one was recorded in Faiyum in low numbers, while the second one was recorded from Giza in a moderate number. Both are phoretic on honeybees as previously noticed by Ghada-Refaei et al. (2018). The families Pygmoforidae Cross and Scutacaridae Oudeman both are represented by a single species, feeding on hive debris or fungi. These two species are Pediculaster sp and Scutacarus evansi Soliman and Kandil at Sharkeia in agreement with Ghada-Refaei (2005). Four species of predaceous are pertaining to the family Cheyletidae Leach, were recorded in association with bees feeding on acarid mite species in beehives [i.e., Acaropsella notchi Volgin, Cheletomorpha lapidopterus, Cheyletus malaccensis Oudemans and Hemechyletia 
bakeri (Ehara)]. The number and localities of occurrence of these four species are recorded in Table (1). These results are similar to those obtained by O'Connor and Klimov (2004). Two families of the Acaridida mites were recorded [Acaridae Ewing and Nesbitt (four species) and Glycyphagidae Berlese (two species)]. Most of these mites are scavengers and cleptoparasites in beehives feeding on fungi, honey, pollen or debris and dead bees. The acarid species were Acarus farris Oudemans, Caloglyphus mycophagus (Megnin), Caloglyphus rhizoglyphoides (Zacbvatkin) and Thyreophagus entomophagus (Laboulbene), while the glycyphagid mite species were Glycyphagous ornatus Kramer and Lapidoglyphus michaeli (Oudemans) with moderate numbers at Giza and Faiyum governorates. The number and localities of occurrence of acarid and glycyphagid mite species are recorded in Table (1). The oribatid mites were represented by two species belonging two families [(Oppia bayoumi Shreef \& Zaher (Oppidae) and Zygoribatulo tameyai El-Badry and Nasr (Oribatulidae)]. These species were collected from the abdomen of dead bees and brood comb samples with a very few numbers at Giza and Sharkeia governorates, wholly in agreement with Ghada-Refaei (2005).

\section{Conclusion}

From the results obtained in the current study it can be concluded that, the occurrence of mites in honey bee may be very dangerous, such as parasitic one, Varroa destructor Anderson and Trueman this species is the most dangerous to bees worldwide and causes severe damage, that may destroy the bees colony. Therefor it is necessary to combat the individuals of the species by using the recommended control methods. While many other species of mites are either predators to the other mites and small arthropods, or they clean the beehives from debris and the bodies of dead bees, which may attract many fungi and other harmful organisms. Therefore, it is necessary to pay attention to these species that are not harmful to beehives and to contact those that may prove to cause harm.

\section{References}

Ahn, A. J., Ahn, K. S. and Noh, J. H. (2015), 'Molecular prevalence of Acarapis mite infestations in honeybees in Korea", Korean Journal of Parasitology, Vol. 53 No. 3, pp. 315-20.

Balogh, J. (1976), "The oribatid genera of the world", Akademiai Kiadó, Budapest, Hungary, pp. 187.

De Jong, D., Morse, R. A. and Eickwort, G. C. (1982) "Mite pests of honeybee", Annual Review of Entomology, Vol. 27, pp. 229-252.

Diana S., Uri G., and Glen N. (2000), "Parasitic mites of honeybees: life history, implications, and impact", 
Annual Review of Entomology, Vol. 45 No. 1, pp. 1519-48

Eickwort, G. C. (1988), "The origins of mites associated with honeybees", Korean Journal of Parasitology, pp. 327-384 4

Evans, G. O. and Till, W. M. (1979), "Mesostigmatic mites of Britain and Ireland (Chelicerata: AcariParasitiformes), and introduction to their external morphology and classification", The Transactions of the Zoological Society of London, Vol. 35 No. 2, pp. 139-270.

Ghada-Refaei, S. M. (2001), Studies on some mites associated with honeybee in Egypt, M.Sc. Thesis, Faculty of Sciences, Cairo University, Egypt, pp. 99.

Ghada-Refaei, S. M. (2005), Studies on some mites and protozoan parasites associated with honeybee in Egypt, Ph.D. Thesis, Faculty of Sciences, Cairo University, Egypt, pp. 159.

Ghada-Refaei, S., Walaa- Abou Zeid, R. and Ola-Roshdy, M. (2018), "Incidence of parasitic and nonparasitic mites of honeybee, Apis mellifera L.", Journal of Plant Protection and Pathology, Vol. 12, No. 29, pp. 873-875.

Hughes, A. M. (1976), The mites of stored food and houses, $2^{\text {nd }}$ edition, Ministry of Agriculture, Fisheries and Food, Technical Bulletin 9, London, United Kingdom, pp. 400.
Krantz, G. W. (1978), A manual of Acarology, Oregon State University Book Stores, Corvallis, USA, pp. 500.

Lindquist, E. E. and Evans, G. O. (1965), "Taxonomic concepts in the Ascidae, with a modification in setal nomenclature for the idiosoma of the Gamasina (Acarina: Mesostigmata)", Memoirs of the Entomological Society of Canada, Vol. 97 No. 47, pp. 5-66

Mordecai, G. J., Wilfert, L., Martin, S. J., Jones, I. M. and Schroeder, D. C. (2016), "Diversity in a honey bee pathogen", first report of a third master variant of the Deformed Wing virus quasispecies", Multidisciplinary Journal of Microbial Ecology, Vol. 10, pp. 1264-1273.

Morse, R. A. (1978), Honeybee pests, predators and diseases, Cornell University Press, Ithaca, New York, USA, pp. 430.

Neumann, P. and Carreck, N. L. (2010), "Honeybee colony losses", Journal of Apicultural Research, Vol. 49, pp. $1-6$.

Oconnor, B. M. and Klimov, P. (2004), Systematics and ecology of North American bee-associated mites: Potential threats to native and introduced pollinators, Miscellaneous Publications of the University of Michigan Museum of Zoology, USA. 
Sammataro, D., Gerson, U. and Needham, G. (2000), "Parasitic mites of honeybee: life history, implications and impact", Annual Review of Entomology, Vol. 45 No. 1, pp. 519548.

Summers, F. M. and Price, D. W. (1970), "Review of the mite family Cheyletidae", Entomology, Vol. 61 No. 1, pp. 1-153.

Wakhal, M. D., Bhujbal, M. and Pais, E. V. D. (1999), "Analysis of honey, pollen and royal jelly by high performance liquid chromatography. A review", Apiacta, Vol. 34, pp. 611.

Ward, K., Danka, R. and Ward, R. (2008), "Comparative performance of two mite-resistant stocks of honeybees (Hymenoptera: Apidae) in Alabama beekeeping operations", Journal Economic of Entomology, Vol. 101 No. 3, pp. 654-659.
Zaher, M. A. (1984), Phytophagous mites in Egypt, Nile valley and Delta: survey and ecological studies on phytophagous, predaceous and soil mites in Egypt, Pl. 480 U.S.A. Project No. EG-ARS-30, Grant No. FG-EGpp. 139:228.

Zaher, M. A. (1986), Survey and ecological studies on phytophagous, predaceous and nonphytophagous mites, PL. 480 programme U.S.A. Project No. EG- ARS- 30 Grant No. FG-EG- pp.139:567. 